\title{
Four-Dimensional Printing Technology at the Frontier of Advanced Modeling and Applications in Brain Tissue Engineering
} Gelişmiş Modellemede Yeni Alan Dört Boyutlu Baskı Teknolojisi ve Beyin Doku Mühendisliğinde Uygulamaları

Merve Nur Soykan ${ }^{1,2}$, Tayfun Şenget ${ }^{2,4}$, Aliakbar Ebrahimi1,5, Murat Kaya', Burcugül Altuğ-Tasa', Hamed Ghorbanpoor ${ }^{1,3}$, Onur Uysal ${ }^{1,2}$, Ayla Eker Sarıboyacl, ${ }^{1,2}$, Hüseyin Avc1 ${ }^{1,25,6}$

1 Cellular Therapy and Stem Cell Production Application and Research Centre, ESTEM, Eskisehir Osmangazi University, Eskisehir, Turkey 2 Department of Stem Cell, Institute of Health Sciences, Eskisehir Osmangazi University, Eskisehir, Turkey 3 Department of Biomedical Engineering, Eskişehir Osmangazi University, Eskişehir, Turkey 4 Central Research Laboratory Research and Application Center, Eskisehir Osmangazi University, Eskisehir, Turkey 5 Department of Metallurgical and Materials Engineering, Eskişehir Osmangazi University, Eskişehir, Turkey

6 Translational Medicine Research and Clinical Center, Eskisehir Osmangazi University, Eskisehir, Turkey

Abstract: The complex process behind the brain topology, which has been extensively studied for the last ten years, is still unclear. Therefore, neural tissue engineering studies are needed to better understand cortical folds. With the development of 4-dimensional (4D) bioprinters using cell-loaded smart materials, a promising path has been opened in the mimicry of the neural tissue. In our study, we review the usage areas of $4 \mathrm{D}$ printers, which have been developing in recent years, in modelling brain tissue. As a result of development of smart materials printed with 3-dimensional (3D) printers caused emerging of $4 \mathrm{D}$ printers, rapidly. Smart materials can change their properties based on physical, chemical and biological stimuli, and this change can be a reversible process. Cell-loaded printed smart materials should have little effect on cell viability of both the incoming stimulus and the physical change. It is also important that the material used is non-toxic and the solvent is suitable for cell viability. On the other hand, hydrogels are frequently studied to mimic the complex neural network of neural tissue. Agents that affect the crosslinking or degree of crosslinking of hydrogels can be easily controlled and changed. In addition, studies with neural stem cells have shown that hydrogels have a supportive effect on the proliferation and maturation of neural stem cells. Since the folding time, strength and location of smart materials cannot be known precisely, it can be an advantage of $4 \mathrm{D}$ bioprinters as it can be controlled and studied whether the results of the stress on the cells in this region will affect other cells. It is an ideal methodology to study the effect of cortical folding on neural stem cells, especially thanks to the ease of experimental manipulations provided by $4 \mathrm{D}$ bioprinters. It is expected that $4 \mathrm{D}$ bioprinters will be adopted and rapid developments will occur in the multidisciplinary field of tissue engineering of brain tissue in the near coming years. Keywords: Neural-tissue engineering, Neural modeling, 4D Printer, Smart biomaterial, Shape memory

Özet: Son on yıldır kapsamlı çalışmalar yapılan beyin topolojisinin arkasında yatan süreç henüz belirsizdir. Kortikal katlanmaların daha iyi anlaşılabilmesi için nöral doku mühendisliği çalışmalarına ihtiyaç vardır. Hücre yüklü akıllı malzemelerin kullanıldığı 4 boyutlu (4B) biyoyazıcıların gelişmesi ile nöral dokunun mimik edilmesinde umut verici bir yol açılmıştır. Çalışmamızda son yıllarda gelişmekte olan 4B yazıcıların beyin dokusunun modellenmesinde kullanım alanlarını gözden geçirmekteyiz. 3 boyutlu (3B) yazıcılar ile basılan akıllı malzemelerin gelişmesiyle 4B yazıcılar ortaya çıkmıştır. Akıllı malzemeler fiziksel, kimyasal ve biyolojik uyaranlara dayalı olarak özelliklerini değiştirebilirler ve bu değişiklik geri dönüşümlü bir süreçtir. Hücre yüklü olarak basılan akıllı malzemeler hem gelen uyarıcının hem de fiziksel değişimin hücre canlılı̆ı üzerinde çok az bir etki yaratması gerekir. Ayrıca kullanılan malzemenin toksik olmaması ve çözücünü hücre canlılığına uygun olması da önemlidir. Nöral dokunun karmaşık sinir ağının mimik edilebilmesi için hidrojeller ile sıklıkla çalışılmaktadır. Hidrojellerin çapraz bağlanmasını veya çapraz bağlanma derecesini etkileyen ajanlar kolaylıkla kontrol edilebilir ve değiştirilebilir. Ayrıca nöral kök hücreler ile yapılan çalışmalarda hidrojellerin nöral kök hücrelerin proliferasyon ve olgunlaşması üzerinde destekleyici bir etkiye sahip olduğu gösterilmiştir. Akıllı malzemelerin katlanma zamanı, kuvveti ve yeri kesin olarak bilinemediği için bu bölgede bulunan hücreler üzerindeki stresin sonuçlarının diğer hücreleri etkileyip etkilemeyeceğinin ön görülmesi zorluğu 4B biyoyazıcıların bir avantajı olarak karşımıza çıkma ihtimalini göstermektedir. Burada özellikle 4B biyoyazııların sağladığı deneysel manipülasyonların kolaylığı sayesinde kortikal katlanmanın nöral kök hücreler üzerine etkisini incelemek için ideal bir metodolojidir. Önümüzdeki yakın yıllarda multidisipliner olan beyin doku mühendisliği alanında 4B biyoyazıcıların benimseneceği ve hızlı gelişmelerin olacağını düşünmekteyiz.

Anahtar Kelimeler: Nöral doku mühendisliği, Nöral modelleme, 4B yazıcı, Akıllı biyomalzeme, Şekil hafızası

Correspondence Address: Merve Nur

SOYKAN Cellular Therapy and Stem Cell

Production Application and Research Centre,

ESTEM, Eskisehir Osmangazi University,

ORCID ID of the authors: M.N.S. 0000-0003-1231-9791, T.Ş. 0000-0002-1162-6979,

A.E. 0000-0001-6437-7796, M.K. 0000-0002-4277-6304, B.A.T. 0000-0003-

4460-8467, H.G. 0000-0002-2665-8172, 0.U. 0000-0001-6800-5607, A.E.S

Eskisehir, Turkey mervesykn@gmail.com

0000-0003-4536-9859, H.A. 0000-0002-2475-1963

Please cite this article in press at: Soykan M.N., Şengel T., Ebrahimi A., Kaya M., Tasa B.A., Ghorbanpoor H., Uysal O., Sarıboyacı A.E., Hüseyin Avcı H., Four-Dimensional Printing Technology at the Frontier of Advanced Modeling and Applications in Brain Tissue Engineering, Journal of Medical Innovation and Technology, 2021; 3 (2):46-57 doi: 10.51934/jomit.1016838

46

๑Copyright 2021 - Journal of Medical Innovation Technology - Available online at www.jomit.org. ๑Telif Hakkı 2021 ESOGÜ Tıp Fakültesi 


\section{Introduction}

The human brain is an organ with a more complex structure compared to other organs in the body. Today, there is still insufficient information about brain development and diseases. Studies with animals for brain studies are limited due to differences in the structure of the animal and human brains. Therefore, human brain-like structures are needed to investigate unknown processes [1]. The topology of brain tissue has been the subject of extensive studies for the last ten years, but the process behind the formation of this topology is still unclear [2]. The folds of the cerebral cortex, called gyri and sulci, are one of the most distinctive features of the mammalian brain. It was believed that during evolution there was a milestone in the formation of cortical folds, which allowed an increase in the number of neurons in the cerebral cortex. An increase in the number of neural progenitors is thought to be responsible for cortical folding [3]. The folding structure of cortical tissues is effective on neurological development of schizophrenia, autism etc. It is known that abnormal cortical folding is responsible for psychotic disorders [4]. In order to better understand the cortical folding, the existing theoretical models have been studied with various materials. However, due to the absence of living cells in these studies, the physiological parameters that closely affect tissue development such as folding and hardening of the material is hard to explain [5].

Neural tissue, which has a cytologically heterogeneous structure, differs mechanically in certain regions due to this heterogeneity. The distribution of cell types in cortical and subcortical tissue, cell migration and proliferation affect the mechanical properties of the tissue and play a role in the folding process. Tissue folding signal starts via cells. The neurological function of normal or abnormal folding is a result of many processes that affect folding. It is essential for neurological diseases to mimic the cortical tissue folding process in a biologically correct and appropriate way during the neural development process.

Neural models have special requirements. These can be neurocompatibility to allow nerve cells to attach and proliferate, elastic properties to mimic the mechanical and physicochemical properties of natural nervous tissue ECM, hierarchical microarchitecture and the ability to induce electroconductivity. The use of cell-loaded smart materials has the advantage of mimicking the mechanical tension associated with cortical folding and imparting neural cell maturation and functionality. In addition to these advantages, the fact that the biomechanical properties can be adjusted and changed in the examination of the folding structure of neurological diseases also allows the creation of the most physiologically correct model [6]. Recent advances in four-dimensional (4D) bioprinters have opened up a promising way to mimic living neural tissue [2]. Due to the wide variety in the field, it would be impossible to cover every facet of subject comprehensively. Therefore, the objective of this review paper is to provide a critical and constructive analysis of the recent literature with a particular focus on development of the technology and their application in neural-tissue engineering.

\section{4-Dimensional (4D) Bioprinter}

Three-dimensional (3D) printing, known as additive manufacturing, is very popular nowadays. Due to the fact that complex objects are produced with high accuracy and with much less waste material, this technique has found numerous practical applications in the automotive, aerospace, energy and other fields $[7,8]$. With the development of 3D-printed structures on the basis of captured tissue photos with medical imaging systems such as computed tomography (CT) and magnetic resonance imaging (MRI), due to the need for high structural complexity and design flexibility for patient-specific surgical models and prostheses should be easily manufactured. One of the advanced additive manufacturing studies is 3D bioprinting, which contributes to the production of tissue-like structures [9-12].

The term 3D bioprinting is used to refer to the layer-bylayer positioning of biological materials, biochemical and living cells to create bioengineered structures that mimic natural living systems. This technology plays a role in ensuring proper spatial and temporal control over cell location, especially in regenerative medicine. As a result, the need for donor organs can be eliminated and the risk of tissue rejection can be reduced However, the sensitivity of living cells, cell types, growth/differentiation factors and material selections in 3D bioprinting are quite complex compared to conventional 3D printing. At the same time, there is a need to develop technical strategies for obtaining living cells and generating 3D structures with appropriate properties for the proper functioning of tissues or organs [13-15].

On the other hand, there may be some limitations in the widespread use of 3D bioprinting. This is because, while native tissues constantly change their morphology to stimuli in their environment, ordinary 3D bioprinted structures cannot elicit appropriate biological responses in their microenvironment. Recently, a new concept called fourdimensional (4D) bioprinting has begun to help alleviate this problem. In this method for fabricating biologically active structures that can adjust their properties to one or more stimuli to achieve the required functionality, the dynamics of natural tissues can be more precisely mimicked when stimuli-sensitive materials are integrated with 3D bioprinting [16-18]. 
4D bioprinting offers very important innovations and advantages under current conditions for productions that cannot be obtained with other biofabrication method such as $3 \mathrm{D}$ printing / bioprinting in order to solve the needs for high resolution dynamic structures. One of the important advantages of $4 \mathrm{D}$ bioprinting is it enables the creation of arbitrary controllable shapes by integrating the time dimension as an additional dimension to the 3 spatial dimensions $(x, y, z)$ of the object $[19,20]$.

Chadwick et al. fabricated 4D cell culture arrays with a temperature-sensitive and shape-memory polymer that can be deformed into a non-permanent deformation and revert to its pre-deformation state when heat-treated to rapidly assess drug responses of glioblastoma patientderived models. These arrays can spontaneously transform from 3D cell culture inserts into histological cassettes over time when heated [21].

Smart materials have a "shape-changing effect (SCE)" due to both their properties and the change of shape of the material or its return to its original state depending on external stimuli. With the SCE feature, the first intelligent material was developed at the Massachusetts Institute of Technology (MIT) [65]. Materials with SCE properties are not homogeneous, on the other hand, they need a stimulus such as light, temperature, humidity, or $\mathrm{pH}$ in order for the shape-changing property to be activated. As the details of the shape changes of intelligent materials in response to stimuli are understood, many types of intelligent materials have been developed and used in practice for the production of precisely programmed 4D bioprints $[12,19]$.

The 4D printer actually gains another dimension by changing shape due to a stimulus, which is obtained by using smart materials in 3D printers. The new dimension to be gained in the product of the $3 \mathrm{D}$ printer is predictable as a result of precise programming. If the material cannot return to its original state after the effect of the stimulus has passed, it is called unidirectional, if it can return, it is called double or multi-directional smart material [13]. After printing on both $3 \mathrm{D}$ and $4 \mathrm{D}$ printers (cell scaffolding) or if there are cells inside the printed material (bioink), these printers are called bioprinters. In 4D bioprints, both the incoming stimulus and the physical change should have very little effect on cell viability. In addition, it is ideal that the material is not toxic to the cell and its solvent is cell culture medium, PBS or water [2].

\section{4D Bioprinting Based On Shape-Transformation Mechanism}

Stimuli-responsive materials or smart materials can change their properties based on physical, chemical and biological stimuli. Physical stimuli (humidity, photo, temperature, acoustic, electro, magnetic), biological stimuli (glucose and enzymes) and chemical stimuli ( $\mathrm{pH}$, ions) materials have the potential to play as an on-off switch system in different areas. These stimuli changes as a response for environmental conditions are reversible process and can be repeated at the same conditions for several times [22]. By changing in structural properties of 3D printed materials as function of time, the capacity and ability of 3D printed materials increase and the fourth dimension was added to system therefore 4D printing concept have been found [23]. Among the different stimuli, water (humidity) was the first stimuli used in 4D bioprinting. When watersensitive materials exposed to surrounding environment, they can absorb or release moistures, and as a results swelling, twisting, folding and other deformations can be stimulated [24].

\subsection{Physical Stimulations}

Physical stimuli such as temperature, liquid/humidity, light, magnetic field, and electrical stimulation have generally caused structural and shape changes in materials sensitive to stimuli, enabling us to obtain materials with unique properties and have led to the use of very different areas in application areas. Using polymers that exhibit different swelling/shrinking behaviors with temperature used as a physical stimulus have been carried out $[25,26]$. Zarek et al. (2017) produced a methacrylate polycaprolactone-based stent in their study. This stent expanded with temperature and developed a stent that fully adapts to this section [27]. In this way, it can be ensured that no injury occurs during the stent placement process and can be expanded and fully conformed afterward. Stoychev et al. (2011) [28] obtained a double-layered polymer using polycaprolactam and poly-( $\mathrm{N}$-isopropyl acrylamide) in their study. While this polymer is in star form at $60^{\circ} \mathrm{C}$, it takes a folded shape at $25^{\circ} \mathrm{C}-33^{\circ} \mathrm{C}$. Apsite et al. (2017) [29] created different bilayer and trilayer structures with electrospinning in their study using PCL and NIPAM. In two-layer films, the fiber structure is designed in parallel direction. While there was no folding in the obtained films at room temperature and dry, different foldings were detected when wet at $20^{\circ} \mathrm{C}$ and $37^{\circ} \mathrm{C}$. The bilayer films are shown to be folded around the long direction with respect to the orientation of the fiber structure when wet and at $20^{\circ} \mathrm{C}$. Wet and $37^{\circ} \mathrm{C}$ both bilayer and trilayer films showed folding around the short direction (Fig. 1). 


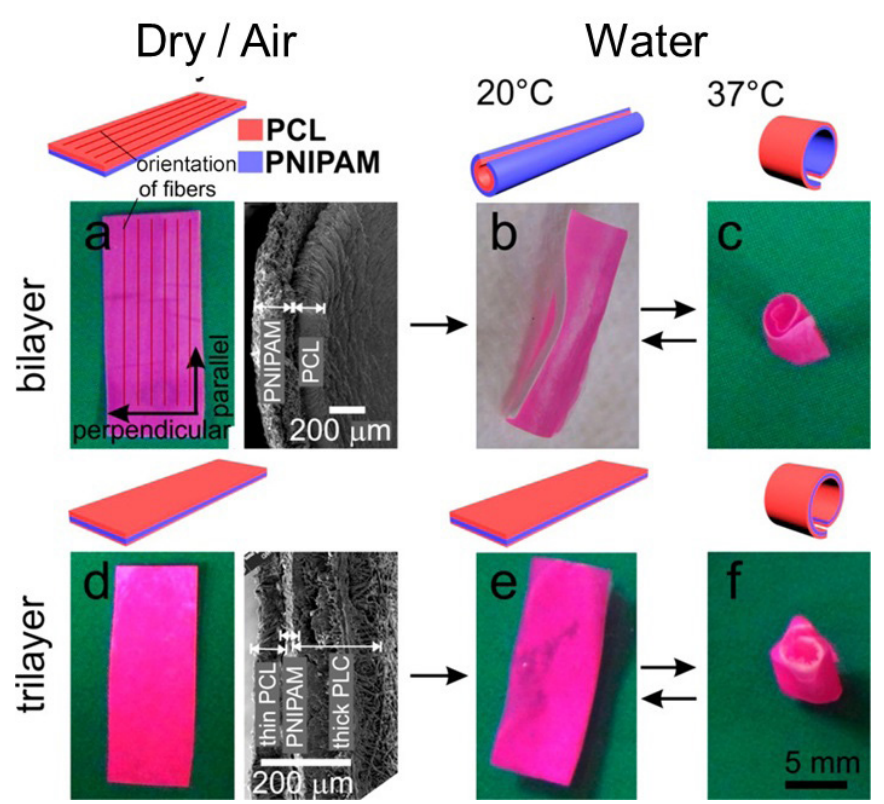

Figure 1. $p$ (NIPAM-BPA)-PCL bilayer and PCL-p(NIPAMBPA)-PCL trilayer electrospun mats: (a) and (d) left, bilayer and trilayer mats no folding is air at room temperature, (b) long-side rolling for bilayer mats (water, $20^{\circ} \mathrm{C}$ ), (c) short-side rolling for bilayer mats (water, 37 ${ }^{\circ} \mathrm{C}$ ), (e) no folding trilayer mats (water, $20^{\circ} \mathrm{C}$ ), (f) shortside rolling for trilayer mats (water, $37^{\circ} \mathrm{C}$ ). Reprinted with permission from [29]. Copyright 2017 American Chemical Society

Another physical factor is liquid/moisture. Humidity is the trigger of some known phenomena in nature. For example, pinecones open under low humidity conditions and release seeds into the environment. Natural events like this have inspired materials that change shape and size with moisture [30]. Cell encapsulation in smart materials is used for controlled drug release or valve-like smart studies with swelling/shrinking. However, these materials have slow response times, poor mechanical properties, and decomposition/hydrolysis properties are important considerations $[16,31]$.

The study of light as a physical stimulus in polymers has led to the development of photosensitive biomedical devices. Size and shape changes, charge formation, photodimerization, and zwitterionic species formation can be induced by light [16]. Gupta et al. (2015) [32] obtained capsules loaded with gold nanorod, PLGA, and therapeutic molecules using a 3D printer (Fig. 2). When these materials were excited with a laser, fragmentation in the shell portion followed by the release of therapeutic molecules was achieved.
Electrosensitive or conductive materials is another physical factor that has come to the fore in recent years, especially because it provides cellular tropism and has positive effects on tissue regeneration $[33,34]$. These materials are polymers that exhibit swelling shrinkage behavior or fold under an external electric field. As electrically steerable materials, this type of perspective can be considered in drug release or repair/ regeneration models. Graphene and carbon nanotubes, which have attracted much attention in recent years and inspired studies with high conductivity, can add durability and electrical conductivity properties to biomaterials. Especially considering conductivity, studies in nerve tissue engineering using $3 \mathrm{D}$ and $4 \mathrm{D}$ bioprinting techniques are promising. Sayyar et al. (2016) and Janus et al. (2015) obtained tissue scaffolds containing various amounts of graphene in their study. These studies with scaffolds have shown that while cellular viability is not affected, they support the differentiation of mesenchymal stem cells due to the application of electricity $[35,36]$.

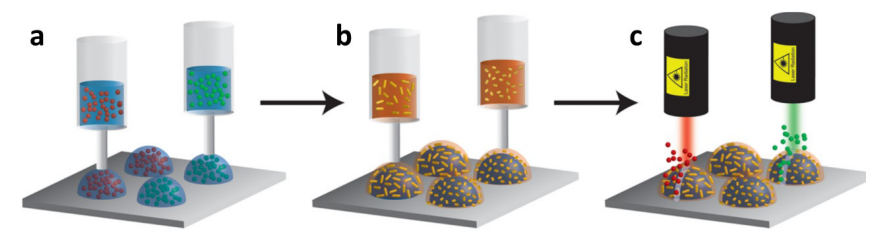

Figure 2. Programmable printing and rupturing of capsules: (a) the core containing biomolecules is printed directly onto a substrate with a 3d printer; (b) PLGA solutions containing gold nanorods are dispensed directly onto the nuclei, resulting in a stimulus-sensitive shell.; (c) The capsules are selectively disintegrated by irradiation with a laser beam. Reprinted with permission from Gupta vd;2017. Copyright 2017 American Chemical Society

\subsection{Chemical Stimulation}

There are two main chemical stimuli materials. $\mathrm{pH}$ responsive materials [37] and ion sensitive hydrogels. $\mathrm{pH}$ responsive materials have weakly acidic $[38,39]$ or weakly basic [40] functional groups like carboxyl, sulfonic, phosphate, and pyridine [16]. At high $\mathrm{pH}$, polymers with weak acidic functional groups (polyacids) release protons to become negatively charged. Polymer chains are approximately very close to each other and as a result the parts of the polymer chains with same charge repulse each other. The same procedure take place for polymers with weak basic functional groups (polybases) as a results of protonation in low $\mathrm{pH}$. Some polymers (collagen, gelatin, and keratin, chitosan, hyaluronic acid, and dextran) are responsive to the environmental $\mathrm{pH}$ 
value. By change in $\mathrm{pH}$, these chemical groups can release or accept protons and swelling or collapsing accrued as result of protonation and deprotonation. These properties can be applied for designing of self-assembled structures $[16,37,41]$.

Ramos et al. offered a low cast strategy for preparing keratin hydrogel that have enhanced mechanical properties. Obtained hydrogel have enough stiffness to handle without any specific cares and also present reversible $\mathrm{pH}-$-responsive character. At low pH minimum amount of swelling was reported as a result of collapsing of protein network and water molecules tightly adsorbed to the hydrophilic areas inside the hydrogel. By increasing the $\mathrm{pH}$ (above the $\mathrm{pH}$ 6), swelling ratio rises sharply and the maximum amount of swelling was reported at $\mathrm{pH}$ above 8 where the expanded network of hydrogel allows water to enter inside the pores [42].

Narupai et al. used protein based material for preparing 3D printed hydrogels and applied them for structural changes (temperature, $\mathrm{pH}$, or an enzyme) that can be controlled and reversible. Methacrylated bovine serum albumin (MA-BSA) with biodegradable character used to Pickering emulsion gels. Hydrogel formation process take place in presence of $\mathrm{N}$-isopropylacrylamide or 2-dimethylaminoethyl methacrylate. Synthesized hydrogels are ideal material for 3D printing of multi-layer stimuli-responsive objects. Poly(N-isopropylacrylamide) P(NIPAAm) and poly(dimethylaminoethyl methacrylate) (P(DMAEMA)) add temperature $(\mathrm{T})$ and $\mathrm{pH}$-responsive character into the obtained hydrogels. Also enzyme-triggered shape change can occur because of the degradation of the BSA network. These hydrogels can reversibly change shape due to by change in temperature or $\mathrm{pH}$, and also enzymatic degradation can occur in irreversible manner and these complex changes could be added to 4D printed systems (Fig. 3) [43].

Another group of chemical stimuli responsive materials are ion-sensitive materials. These materials have the sensitivity to ionic concentration of the surrounding environment $[22,24,44]$. Some of ion sensitive materials, especially ion-sensitive hydrogels, have capability of introducing to 4D bioprinting systems. In these materials, crosslinking and dissociation between the polymer chains as a result of interacting with ions is the base of their ionsensitive behavior [45]. Like $\mathrm{pH}$ responsive materials, in ion-responsive hydrogels the polymer chains are mainly linked through electrostatic interactions, decrease or increase of the ion concentration can change the strength of the electrostatic interaction and effect the behavior of the hydrogels.
Alginates as an ion-senstive gels is a case in point. Alginates have ability to create ion-senstive gels by electrostatic crosslinking. So they have potential for creating in situ gellable materials in presence of divalent cationic environments such as $\mathrm{Ca} 2+[45]$.

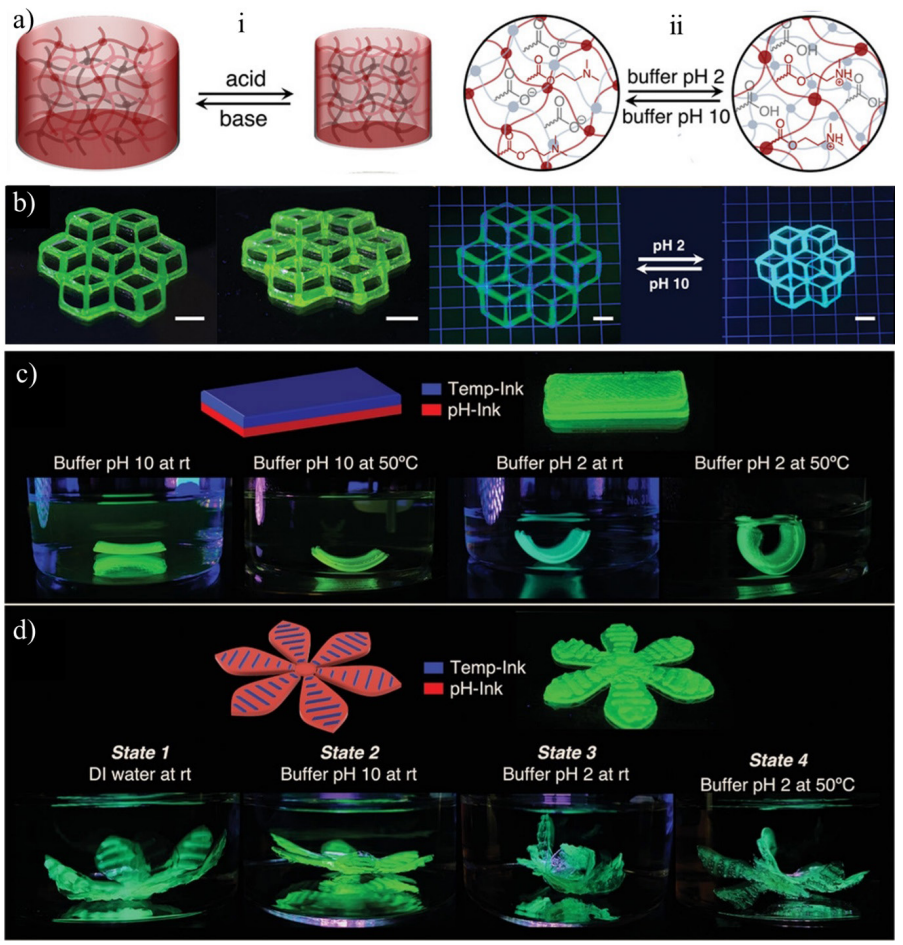

Figure 3. a) i. after photopolymerization, the $\mathrm{pH}$-sensitive hydrogel shrinks reversibly when immersed in acidic solution and expanded when immersed in basic solution, ii. Chemical composition of the $\mathrm{pH}$ responsive hydrogel: amine (P(DMAEMA)) and carboxylic acid (MA--BSA) groups. b) 3D printed structure and $\mathrm{pH}$ response of the hydrogel. $\mathrm{c}$ and d) Multiple shape transformations of 3D printed hydrogel structures. c) $\mathrm{pH}$ and temperature-responsive bilayer. d) Complex flower morphology using $\mathrm{pH}$-Ink for petals and Temp-Ink for lines across each petal. Reprinted with permission from [43] Copyright (2021) John Wiley and Sons.

Wang et al. reported design and synthesize of fluorochromic hydrogels that are sensitive to light and ferric ion (Fe3+) [47]. These hydrogels have high strength and self-healing ability. Poly(vinyl alcohol) (PVA) physically cross-linked in the presence of tannic acid and $\gamma$-cyclodextrin-spiropyran $(\gamma-C D-S P)$ and PVA based hydrogel were synthesized. Formation of Hydrogen bonds between the PVA chain and $\gamma-C D$ moiety, allow the fluorophore $\gamma-C D-S P$ addition inside the PVA gel. The hydrogel have "on/off" fluorescence property due to photo-isomerization character of the SP moiety. The fluorescence emission property of hydrogel can be turned off by adding $\mathrm{Fe} 3+$ as result of fluorescence inner filter effects, and the process can be recovered by adding EDTA. These properties (high strength, self-healing, 
and tunable fluorescence) make the hydrogels capable materials for use in optical switches, wearable devices, and fluorescent sensors.

\subsection{Biological Stimulation}

There is always a signal-response system in the human body. For example, blood sugar is constantly regulated by insulin secretion. In today's studies, studies aimed at gaining sensitive behavior when interacting with free-form materials gain importance [16].

Glucose is the most frequently found free biochemical in the blood and is the most important marker of diabetes; the diagnosis and follow-up are the most difficult. Glucose-sensitive polymers respond to changes in glucose concentration and are promising in targeted diabetes treatment applications. As diabetes becomes one of the social health problems, interest in a glucose-sensitive polymer is increasing. The change in glucose concentration causes a change in the properties of the polymer [48].

Considering the studies, there are studies on determining the glucose level by amperometric method from conductive polymeric structures modified with glucose dehydrogenase or glucose oxidase. In these studies, the detection range was $0-400 \mathrm{mg} / \mathrm{dL}$ [49]. Both the monitoring of blood glucose levels and the timely use of regulatory drugs are essential for the prognosis of diabetes. While innovative technologies are used in sensors to monitor blood levels, studies have recently been conducted on releasing insulin from the polymer depending on the glucose level in drug delivery systems. In these studies, insulin release occurs either due to polymeric hydrolysis after the interaction of glucose oxidase with glucose or due to the binding of glucose in the polymeric membrane structure of insulin $[50,51]$. Enzymes such as glucose are free materials in the blood or body. Enzymes are important compounds that catalyze various reactions in the human body and are involved in particular reactions. The ability of enzymes to cleave specific bonds in the engineered natural or synthetic polymer is a critical approach. Enzyme-sensitive polymers have a significant advantage in drug delivery due to their self-occurrence in the biological environment. However, there are important issues such as the polymers to be designed do not react with other enzymes, be biocompatible, non-toxic, and release active compounds such as drugs in the target tissue [52].

At the beginning of these studies is drug retention in polymeric structure or side chains and its degradation by enzyme release. In this way, it is possible to develop materials that can be tissue or disease-specific applications
[53]. Apart from these, soft robotic approaches that have come to the fore recently are based on structures produced from enzymatically degradable materials. These tiny devices have shown great potential in targeted drug delivery, microsurgery, and detection and diagnosis. A significant challenge in small-scale biomedical robotics is to design functional micro and nanostructures that can perform multiple tasks and be implanted in the body (Fig. 4) [54]. Current trends in micro and nanorobots are towards adopting soft materials that are more suitable for biomedical applications because their physicochemical properties are more similar to those of tissues $[53,54]$. a

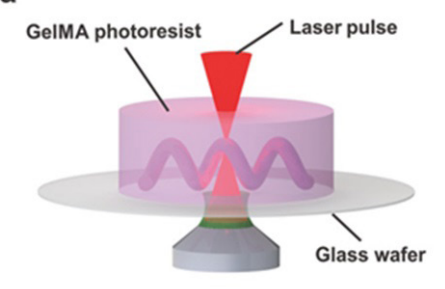

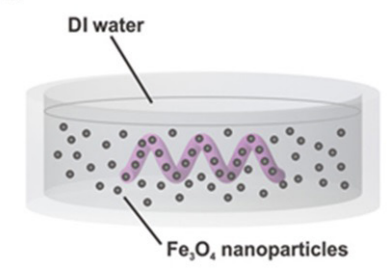

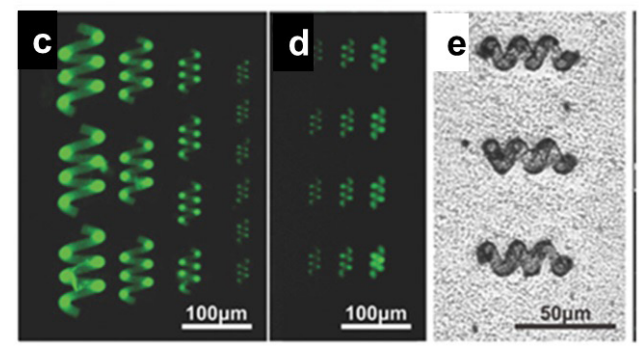

f

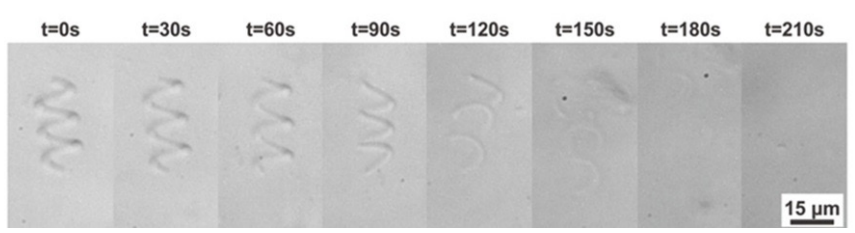

Figure 4. Biodegradable GelMA helical microswimmers: a) Photoresist is used to print GelMA helical structures; and b) decorated with magnetic nanoparticles; c) and d) fluorescent microscope images of helical structures of different sizes and thicknesses. e) Optical image of helical microswimmers decorated with magnetic nanoparticles. f) Time-dependent degradation of helical structures in collagenase solution $\left(0.1 \mathrm{mg} \mathrm{mL}^{-1}\right)$. Reprinted with permission from [54]. Copyright 2018 WILEY-VCH Verlag GmbH \& Co. KGaA, Weinheim.

\section{Applications of 4D Printing in Neural-Tissue Engineering}

The materials, which can best mimic the complex nerve structure in the tissue can be hydrogels. Because the agents that affect the crosslinking of hydrogels or the degree of crosslinking can be easily controlled and changed with adding a various supportive materials. In 
addition, studies have found that it has an encouraging effect on the proliferation and maturation of neural stem cells [55]. However, since the precise time, force and location of folding in smart materials used in 4D bioprinters are not controlled, it is not known which consequences of the stress will be on the cells in the region of folding. In 4D prints with hydrogel material, it has been shown that cells can move to the upper and lower points where they form the folds [56].

The current literature on 4D bioprinting of nerve tissues is very limited. Some of the studies using 3D and 4D bioprinters are compared and shown in Table 1. A brief summary of the literature has been investigated to describe the advantages and deficiencies in 3D bioprinting studies while moving towards $4 \mathrm{D}$ models. Lozano et al. produced a six-layer cerebral cortex model. For their study, the new RGD-peptide-modified Gellan Gum (GG) bioink was developed to encapsulate primary cortical neurons which modeled from mouse embryos. Cells encapsulated with a bioink 5X DMEM and $1 \mathrm{M}$ calcium chloride which can be cross-linked without toxic effects. In this study, it was determined that the encapsulated cells continued to grow, divide and form neural networks during the 5-day culture period, and occurred axonal development from the cellloaded layers to the empty layers [57]. In another study, the viability and proliferation of cells were evaluated in order to form tissue grafts for regenerative medicine with inject printing technology using retinal ganglion and glia cells, which are cells of the adult rat central nervous system [58].

The structure and development of neural tissue have significant role when mimicking the folding process of cortical tissue with 4D bioprinters. For instance, it must be similar to the tissue network of gray and white matter in vivo for biomimicking neural tissue. Considering this situation, 4D printing are carried with brain gray matter modulus 0.68 $\pm 0.20 \mathrm{kPa}$, cerebral white matter modulus $1.41 \pm 0.66 \mathrm{kPa}$, and cerebellum modulus $0.75 \pm 0.29 \mathrm{kPa}$ [2]. Moreover, biomimicry of neural tissue must have a folding rate similar to in vivo in order to mimic the folding of cortical tissue. In other words, in order to biomimic the cortical tissue, it is necessary to model it to fold or form a flat structure for 10 or more weeks in in vitro conditions. Heat-sensitive shape memory polymers (SMPs) can be used to mimic neural tissue. They are thermosetting polymeric compounds that are easy to modify, but the shape given by heat is permanent [59]. However, in recent studies, SMPs varieties have been applied that can be folded $180^{\circ}$ by changing the formulation of SMP polymers and can be restored at $37^{\circ} \mathrm{C}$. For example, soybean oil epoxidized acrylate can recover its former structures at $37^{\circ} \mathrm{C}$ (Fig. 5a) [60]. Miao et al., successfully produced a $4 \mathrm{D}$-printed graphene-enabled polymeric nerve routing channel that can be used for directing guidance of stem cell growth (Fig. $5 b-5 d$ ). They produced it for regeneration of the peripheral nervous system using custom-made stereolithography. Human bone marrow mesenchymal stem cells (hMSCs) were demonstrated to sequence in an aligned manner on scaffolds created using a $4 \mathrm{D}$ printer. It was shown that the 4D-printed scaffold improved expression of neurogenic factors ND1, NSE and Ngn2 in comparison of control samples. Moreover, the spatial features required for neural development safely increased neurogenesis. In this study, naturally derived memory polymer $4 \mathrm{D}$ effect is suitable for thermomechanical programming [61].

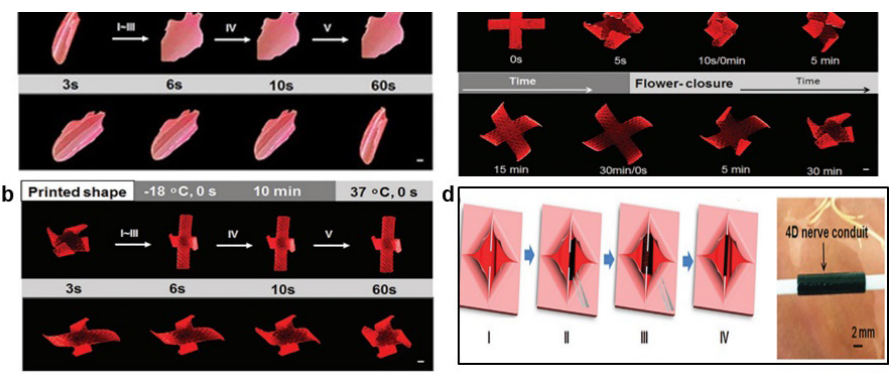

Figure 5. a and b) SOEA-based materals that can temporarily take a flat shape at $-18^{\circ} \mathrm{C}$ and fully recover their original shape at $37^{\circ} \mathrm{C}$. (Reprinted with permissions from [60] Copyright (2019) Taylor \& Francis Online and [60] Copyright (2018) John Wiley and Sons). c) Photographs of the reversible shape process with a 4D-printed flower structure that can be opened in ethanol and closed in water. (Reprinted with permission from [60] Copyright (2018) John Wiley and Sons). d) 4D nerve guidance conduit, Schematic of the selfentubulation in a damaged nerve (I-IV). (Scale bar, $2 \mathrm{~mm}$ ). (Reprinted with permission from [61] Copyright (2018) John Wiley and Sons). 
Table 1. Summary of recent researches on 3D and 4D printing for neural-tissue engineering.

\begin{tabular}{|c|c|c|}
\hline Approach & 3D Printing & 4D Printing \\
\hline 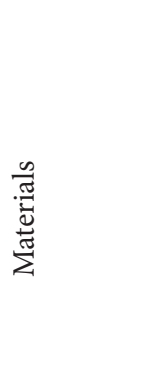 & $\begin{array}{c}\text { Gellan gum-RGD (RGD-GG) } \\
\text { CN7] } \\
\text { CNS grafts [58] } \\
\text { 10\% GelMA and 15\% PEGDA } \\
\text { [63] } \\
\text { S 4-arm PLA [64] }\end{array}$ & $\begin{array}{l}\text { SOEA [61] } \\
\text { AlgGel [62] }\end{array}$ \\
\hline 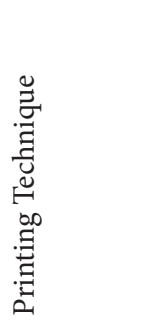 & $\begin{array}{l}\text { Harpool Luer-lock syringes [57] } \\
\text { Piezoelectric inkjet printing [58] } \\
\text { Stereolithography-based 3D } \\
\text { printer [63] } \\
\text { A direct laser write (DLW) [64] }\end{array}$ & $\begin{array}{c}\text { Stereolithographic [61] } \\
\text { XY-axis positioning system } \\
\text { [62] }\end{array}$ \\
\hline 总 & & $\begin{array}{c}\text { Ethanol [61] } \\
\text { Calcium-free PBS [62] }\end{array}$ \\
\hline 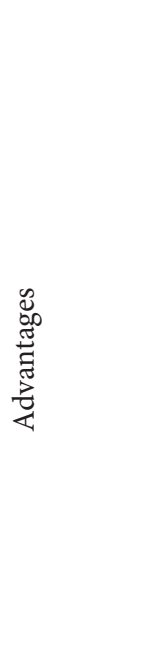 & $\begin{array}{l}\text { Opportunity to provide a more } \\
\text { accurate representation of 3D in vivo } \\
\text { environments with applications rang- } \\
\text { ing from cell behavior studies [57] } \\
\text { Opening new avenues for printed } \\
\text { CNS grafts in regenerative medicine } \\
\text { [58] } \\
\text { 3D printing technology is superior } \\
\text { to many other conventional scaffold } \\
\text { fabrication approaches regarding } \\
\text { the design and controllability of } \\
\text { architecture [63] } \\
\text { Good mechanical properties [64] }\end{array}$ & $\begin{array}{l}\text { Creating multirespon- } \\
\text { sive smart architectures } \\
\text { [61] } \\
\text { 4D-printing platform } \\
\text { suitable for engineer- } \\
\text { ing a wide range of } \\
\text { tissues, particularly for } \\
\text { microscopic tissues that } \\
\text { require proper controls } \\
\text { of cell distribution and } \\
\text { cell-cell organization } \\
\text { [62] }\end{array}$ \\
\hline
\end{tabular}

\section{Conclusions and Future Perspective of 4D Bioprinting}

Even if the exciting developments brought by $4 \mathrm{D}$ bioprinting and predicting the possible changes that occur after process, intensive research and studies are needed to carry out. Especially in studies where living cells are used, changes in the biostructures during and after the bioprinting and their least effects should be precisely expected. Therefore, much more attention should be paid to the structural design of biostructures and biomaterials, and especially to other materials used such as crosslinkers. Combinational 3D and 4D studies can be used to interrogate and validate differential growth pattern and axonal tension patterns, as well as to evaluate the effects of mechanical stresses on neurodevelopment. In particular, the 4D bioprinter approach is an excellent methodology for studying the effects of cortical folding on stem cell proliferation and maturation, due to the ease of experimental manipulation and remarkable modifiability which provides. While the 4D bioprinter is still in its infancy as a fully fabrication technique, it may be rapidly adopted in the various tissue engineering disciplines include organ on a chip in the near coming years [66-70].

\section{Acknowledgement}

We gratefully acknowledge Turkish Scientific and Technological Council (TÜBITAK) and Eskisehir Osmangazi University (Scientific Research Foundation) for their support. 


\section{References}

1. Rothenbücher, T. S., Gürbüz, H., Pereira, M. P., Heiskanen, A., Emneus, J., \& Martinez-Serrano, A. (2021). Next generation human brain models: engineered flat brain organoids featuring gyrification. Biofabrication, 13(1), 011001. doi: 10.1088/1758-5090/abc95e

2. Esworthy, T. J., Miao, S., Lee, S. J., Zhou, X., Cui, H., Zuo, Y. Y., \& Zhang, L. G. (2019). Advanced 4D-bioprinting technologies for brain tissue modeling and study. International journal of smart and nano materials, 10(3), 177-204. doi: 10.1080/19475411.2019.1631899

3. Matsumoto, N., Shinmyo, Y., Ichikawa, Y., \& Kawasaki, H. (2017). Gyrification of the cerebral cortex requires FGF signaling in the mammalian brain. Elife, 6, e29285 doi: 10.7554/eLife. 29285

4. Nanda, P., Tandon, N., Mathew, I. T., Giakoumatos, C. I., Abhishekh, H. A., Clementz, B. A., Pearlson, G. D., Sweeney, J., Tamminga, C. A., \& Keshavan, M. S. (2014). Local gyrification index in probands with psychotic disorders and their first-degree relatives. Biological psychiatry, 76(6), 447-455. doi: 10.1016/j.biopsych.2013.11.018

5. Thompson AJ, Pillai EK, Dimov IB, Foster SK, Holt CE, Franze K. Rapid changes in tissue mechanics regulate cell behaviour in the developing embryonic brain. Elife. 2019 Jan 15;8:e39356. doi: 10.7554/eLife.39356.

6. Askari, M., Naniz, M. A., Kouhi, M., Saberi, A., Zolfagharian, A., \& Bodaghi, M. (2021). Recent progress in extrusion 3D bioprinting of hydrogel biomaterials for tissue regeneration: A comprehensive review with focus on advanced fabrication techniques. Biomaterials science, 9(3), 535-573. doi: 10.1039/DOBM00973C

7. Gao, W., Zhang, Y., Ramanujan, D., Ramani, K., Chen, Y., Williams, C. B., ... \& Zavattieri, P. D. (2015). The status, challenges, and future of additive manufacturing in engineering. Computer-Aided Design, 69, 65-89. doi: 10.1016/j. cad.2015.04.001.

8. Farahani, R. D., Dubé, M., \& Therriault, D. (2016). Three $\square$ dimensional printing of multifunctional nanocomposites: manufacturing techniques and applications. Advanced materials, 28(28), 5794-5821. doi: 10.1002/adma.201506215

9. Lee Ventola, C. (2014). Medical applications for 3D printing: current and projected uses, P T 39 (2014) 704-711
10. Guvendiren, M., Molde, J., Soares, R. M., \& Kohn, J. (2016). Designing biomaterials for 3D printing. ACS biomaterials science \& engineering, 2(10), 1679-1693. doi: 10.1021/ acsbiomaterials.6b00121.

11. Kahl, M., Gertig, M., Hoyer, P., Friedrich, O., \& Gilbert, D. F. (2019). Ultra-low-cost 3D bioprinting: modification and application of an off-the-shelf desktop 3D-printer for biofabrication. Frontiers in bioengineering and biotechnology, 7, 184. doi: 10.3389/fbioe.2019.00184.

12. Gao, B., Yang, Q., Zhao, X., Jin, G., Ma, Y., \& Xu, F. (2016). 4D bioprinting for biomedical applications. Trends in biotechnology, 34(9), 746-756. doi: 10.1016/j.tibtech.2016.03.004

13. Mota, C., Camarero-Espinosa, S., Baker, M. B., Wieringa, P., \& Moroni, L. (2020). Bioprinting: from tissue and organ development to in vitro models. Chemical reviews, 120(19), 10547-10607. doi: 10.1021/acs.chemrev.9b00789.

14. Cui, H., Nowicki, M., Fisher, J. P., \& Zhang, L. G. (2017). 3D bioprinting for organ regeneration. Advanced healthcare materials, 6(1), 1601118. doi: 10.1002/adhm.201601118.

15. Xie, Z., Gao, M., Lobo, A. O., \& Webster, T. J. (2020). 3D bioprinting in tissue engineering for medical applications: the classic and the hybrid. Polymers, 12(8), 1717. doi: 10.3390/POLYM12081717.

16. Wan, Z., Zhang, P., Liu, Y., Lv, L., \& Zhou, Y. (2020). Four-dimensional bioprinting: Current developments and applications in bone tissue engineering. Acta biomaterialia, 101, 26-42. doi: 10.1016/j.actbio.2019.10.038.

17. Yu, C., Ma, X., Zhu, W., Wang, P., Miller, K. L., Stupin, J., ... \& Chen, S. (2019). Scanningless and continuous 3D bioprinting of human tissues with decellularized extracellular matrix. Biomaterials, 194, 1-13. doi: 10.1016/j. biomaterials.2018.12.009.

18. Li, Y. C., Zhang, Y. S., Akpek, A., Shin, S. R., \& Khademhosseini, A. (2016). 4D bioprinting: the nextgeneration technology for biofabrication enabled by stimuli-responsive materials. Biofabrication, 9(1), 012001. doi: 10.1088/1758-5090/9/1/012001.

19. Yang, G. H., Yeo, M., Koo, Y. W., \& Kim, G. H. (2019). 4D bioprinting: technological advances in biofabrication. Macromolecular bioscience, 19(5), 1800441. doi: 10.1002/ mabi.201800441. 
20. Zhang, Z., Demir, K. G., \& Gu, G. X. (2019). Developments in 4D-printing: a review on current smart materials, technologies, and applications. International Journal of Smart and Nano Materials, 10(3), 205-224. doi: 10.1080/19475411.2019.1591541.

21. Chadwick, M., Yang, C., Liu, L., Gamboa, C. M., Jara, K., Lee, H., \& Sabaawy, H. E. (2020). Rapid processing and drug evaluation in glioblastoma patient-derived organoid models with 4D bioprinted arrays. Iscience, 23(8), 101365. doi: 10.1016/j.isci.2020.101365.

22. Amukarimi, S., \& Mozafari, M. (2021). 4D bioprinting of tissues and organs. Bioprinting, e00161. doi: 10.1016/j. bprint.2021.e00161

23. Nadgorny, M., \& Ameli, A. (2018). Functional polymers and nanocomposites for $3 \mathrm{D}$ printing of smart structures and devices. ACS applied materials \& interfaces, 10(21), 17489-17507. doi: 10.1021/acsami.8b01786

24. Yang, Q., Gao, B., \& Xu, F. (2020). Recent advances in 4D bioprinting. Biotechnology journal, 15(1), 1900086. doi: 10.1002/biot.201900086

25. Klouda, L., \& Mikos, A. G. (2008). Thermoresponsive hydrogels in biomedical applications. European journal of pharmaceutics and biopharmaceutics, 68(1), 34-45. doi: 10.1016/j.ejpb.2007.02.025

26. Wang, X., Sun, Y., Peng, C., Luo, H., Wang, R., \& Zhang, D. (2015). Transitional suspensions containing thermosensitive dispersant for three-dimensional printing. ACS applied materials \& interfaces, 7(47), 26131-26136. doi: 10.1021/ acsami.5b07913

27. Zarek, M., Mansour, N., Shapira, S., \& Cohn, D. (2017). 4D printing of shape memorybbased personalized endoluminal medical devices. Macromolecular rapid communications, 38(2), 1600628. doi: 10.1002/marc.201600628

28. Stoychev, G., Puretskiy, N., \& lonov, L. (2011). Self-folding all-polymer thermoresponsive microcapsules. Soft Matter, 7(7), 3277-3279. doi: 10.1039/C1SM05109A

29. Apsite, I., Stoychev, G., Zhang, W., Jehnichen, D., Xie, J., \& lonov, L. (2017). Porous stimuli-responsive self-folding electrospun mats for $4 \mathrm{D}$ biofabrication. Biomacromolecules, 18(10), 3178-3184.
30. Fratzl, P., \& Barth, F. G. (2009). Biomaterial systems for mechanosensing and actuation. Nature, 462(7272), 442-448.

31. Lui, Y. S., Sow, W. T., Tan, L. P., Wu, Y., Lai, Y., \& Li, H. (2019). 4D printing and stimuli-responsive materials in biomedical aspects. Acta biomaterialia, 92, 19-36. doi: 10.1016/j. actbio.2019.05.005

32. Gupta, M. K., Meng, F., Johnson, B. N., Kong, Y. L., Tian, L., Yeh, Y. W., ... \& McAlpine, M. C. (2015). 3D printed programmable release capsules. Nano letters, 15(8), 5321-5329. doi: 10.1021/acs.nanolett.5b01688

33. Ahadian, S., Obregón, R., Ramón-Azcón, J., Salazar, G., Shiku, H., Ramalingam, M., \& Matsue, T. (2016). Carbon nanotubes and graphene-based nanomaterials for stem cell differentiation and tissue regeneration. Journal of Nanoscience and Nanotechnology, 16(9), 8862-8880. doi: 10.1166/jnn.2016.12729

34. Ramon-Azcon, J., Ahadian, S., Obregon, R., Shiku, H., Ramalingam, M., \& Matsue, T. (2014). Applications of carbon nanotubes in stem cell research. Journal of biomedical nanotechnology, 10(10), 2539-2561. doi: 10.1166/jbn.2014.1899

35. Sayyar, S., Bjorninen, M., Haimi, S., Miettinen, S., Gilmore, K., Grijpma, D., \& Wallace, G. (2016). UV cross-linkable graphene/poly (trimethylene carbonate) composites for 3D printing of electrically conductive scaffolds. ACS applied materials \& interfaces, 8(46), 31916-31925. doi: 10.1021/ acsami.6b09962

36. Jakus, A. E., Secor, E. B., Rutz, A. L., Jordan, S. W., Hersam, M. C., \& Shah, R. N. (2015). Three-dimensional printing of high-content graphene scaffolds for electronic and biomedical applications. ACS nano, 9(4), 4636-4648. doi: 10.1021/acsnano.5b01179

37. Kocak, G., Tuncer, C. A. N. S. E. L., \& Bütün, V. J. P. C. (2017). pH-Responsive polymers. Polymer Chemistry, 8(1), 144-176. doi: 10.1039/C6PY01872F

38. Pourjavadi, A., Ebrahimi, A. A., \& Barzegar, S. (2013). Preparation and evaluation of bioactive and compatible starch based superabsorbent for oral drug delivery systems. Journal of Drug Delivery Science and Technology, 23(5), 511-517. doi: 10.1016/S1773-2247(13)50074-8 
39. Kwon, S. S., Kong, B. J., \& Park, S. N. (2015). Physicochemical properties of $\mathrm{pH}$-sensitive hydrogels based on hydroxyethyl cellulose-hyaluronic acid and for applications as transdermal delivery systems for skin lesions. European journal of pharmaceutics and biopharmaceutics, 92, 146-154. doi: 10.1016/j.ejpb.2015.02.025

40. Fundueanu, G., Constantin, M., Asmarandei, I., Harabagiu, V., Ascenzi, P., \& Simionescu, B. C. (2013). The thermosensitivity of $\mathrm{pH} /$ thermoresponsive microspheres activated by the electrostatic interaction of $\mathrm{pH}$ Dsensitive units with a bioactive compound. Journal of Biomedical Materials Research Part A, 101(6), 1661-1669. doi: 10.1002/ jbm.a.34469

41. Kim, S. H., Seo, Y. B., Yeon, Y. K., Lee, Y. J., Park, H. S., Sultan, M. T., ... \& Park, C. H. (2020). 4D-bioprinted silk hydrogels for tissue engineering. Biomaterials, 260, 120281. doi: 10.1016/j.biomaterials.2020.120281

42. Ramos, M. L. P., González, J. A., Fabian, L., Pérez, C. J., Villanueva, M. E., \& Copello, G. J. (2017). Sustainable and smart keratin hydrogel with $\mathrm{pH}$-sensitive swelling and enhanced mechanical properties. Materials Science and Engineering: C, 78, 619-626. doi: 10.1016/j.msec.2017.04.120

43. Narupai, B., Smith, P. T., \& Nelson, A. (2021). 4D Printing of MultiDStimuli Responsive ProteinDBased Hydrogels for Autonomous Shape Transformations. Advanced Functional Materials, 2011012. doi: 10.1002/adfm.202011012

44. Yoshida, T., Lai, T. C., Kwon, G. S., \& Sako, K. (2013). $\mathrm{pH}$-and ion-sensitive polymers for drug delivery. Expert opinion on drug delivery, 10(11), 1497-1513. doi: $10.1517 / 17425247.2013 .821978$

45. Dong, Y., Wang, S., Ke, Y., Ding, L., Zeng, X., Magdassi, S., \& Long, Y. (2020). 4D printed hydrogels: fabrication, materials, and applications. Advanced Materials Technologies, 5(6), 2000034. doi: 10.1002/admt.202000034

46. Rudko, M., Urbaniak, T., \& Musiat, W. (2021). Recent Developments in lon-Sensitive Systems for Pharmaceutical Applications. Polymers, 13(10), 1641. doi: 10.3390/ polym13101641

47. Wang, B., Liu, L., \& Liao, L. (2019). Light and ferric ion responsive fluorochromic hydrogels with high strength and self-healing ability. Polymer Chemistry, 10(47), 6481-6488. doi: 10.1039/C9PY01459D
48. Wu, Q., Wang, L., Yu, H., Wang, J., \& Chen, Z. (2011). Organization of glucose-responsive systems and their properties. Chemical reviews, 111(12), 7855-7875. doi: $10.1021 / \mathrm{cr} 200027 \mathrm{j}$

49. Adams, A., Malkoc, A., \& La Belle, J. T. (2018). The development of a glucose dehydrogenase 3D-printed glucose sensor: a proof-of-concept study. Journal of diabetes science and technology, 12(1), 176-182. doi: $10.1177 / 1932296817715272$

50. Matsumoto, A., Ishii, T., Nishida, J., Matsumoto, H., Kataoka, K., \& Miyahara, Y. (2012). A synthetic approach toward a selfuregulated insulin delivery system. Angewandte Chemie International Edition, 51(9), 2124-2128. doi: 10.1002/anie. 201106252

51. Brownlee, M., \& Cerami, A. (1979). A glucose-controlled insulin-delivery system: semisynthetic insulin bound to lectin. Science, 206(4423), 1190-1191. doi: 10.1126/ science. 505005

52. Wang, J., Zhang, H., Wang, F., Ai, X., Huang, D., Liu, G., \& Mi, P. (2018). Enzyme-responsive polymers for drug delivery and molecular imaging. In Stimuli Responsive Polymeric Nanocarriers for Drug Delivery Applications, Volume 1 (pp. 101-119). Woodhead Publishing. doi: 10.1016/ B978-0-08-101997-9.00004-7

53. Zelzer, M., Todd, S. J., Hirst, A. R., McDonald, T. 0., \& Ulijn, R. V. (2013). Enzyme responsive materials: design strategies and future developments. Biomaterials Science, 1(1), 11-39. doi: 10.1039/C2BM00041E

54. Wang, X., Qin, X. H., Hu, C., Terzopoulou, A., Chen, X. Z., Huang, T. Y., ... \& Nelson, B. J. (2018). 3D printed enzymatically biodegradable soft helical microswimmers. Advanced Functional Materials, 28(45), 1804107. doi: 10.1002/adfm.201804107

55. Banerjee, A., Arha, M., Choudhary, S., Ashton, R. S., Bhatia, S. R., Schaffer, D. V., Kane, R. S. (2009). The influence of hydrogel modulus on the proliferation and differentiation of encapsulated neural stem cells. Biomaterials. Sep;30(27):4695-9. doi: 10.1016/j.biomaterials.2009.05.050. Epub 2009 Jun 17. 
56. Chang, Y. J., Tsai, C. J., Tseng, F. G., Chen, T. J., Wang, T. W. (2013). Micropatterned stretching system for the investigation of mechanical tension on neural stem cells behavior. Nanomedicine. Apr;9(3):345-55. doi: 10.1016/j. nano.2012.07.008. Epub 2012 Aug 24.

57. Lozano, R., Stevens, L., Thompson, B. C., Gilmore, K. J., Gorkin III, R., Stewart, E. M., in het Panhuis, M., Romero-Ortega, M. and Wallace, G.G. (2015). 3D printing of layered brain-like structures using peptide modified gellan gum substrates. Biomaterials, 67, 264-273. doi:10.1016/j. biomaterials.2015.07.022

58. Lorber, B., Hsiao, W. K., Hutchings, I. M., \& Martin, K. R. (2013). Adult rat retinal ganglion cells and glia can be printed by piezoelectric inkjet printing. Biofabrication, 6(1), 015001. doi:10.1088/1758-5082/6/1/015001

59. Miao, S., Castro, N., Nowicki, M., Xia, L., Cui, H., Zhou, X., Zhu, W., Lee, S. J., Sarkar, K., Vozzi, G., Tabata, Y., Fisher, J., \& Zhang, L. G. (2017). 4D printing of polymeric materials for tissue and organ regeneration. Materials today (Kidlington, England), 20(10), 577-591. doi: 10.1016/j.mattod.2017.06.005

60. Miao, S., Cui, H., Nowicki, M., Lee, S.J., Almeida, J., Zhou, X., Zhu, W., Yao, X., Masood, F., Plesniak, M.W. and Mohiuddin, M., 2018. Photolithographic-stereolithographictandem fabrication of 4D smart scaffolds for improved stem cell cardiomyogenic differentiation. Biofabrication, 10(3), p.035007. https://doi.org/10.1088/1758-5090/aabe0b

61. Miao, S., Cui, H., Nowicki, M., Xia, L., Zhou, X., Lee, S. J., ... \& Zhang, L. G. (2018). Stereolithographic 4D bioprinting of multiresponsive architectures for neural engineering. Advanced biosystems, 2(9), 1800101. https://doi.org/10.1002/ adbi.201800101

62. Cui, C., Kim, D. O., Pack, M. Y., Han, B., Han, L., Sun, Y., \& Han, L. H. (2020). 4D printing of self-folding and cell-encapsulating 3D microstructures as scaffolds for tissue-engineering applications. Biofabrication, 12(4), 045018.

63. Zhu, W., George, J. K., Sorger, V. J., \& Grace Zhang, L. (2017). 3D printing scaffold coupled with low level light therapy for neural tissue regeneration. Biofabrication, 9(2), 025002. doi:10.1088/1758-5090/aa6999

64. Melissinaki, V., Gill, A. A., Ortega, I., Vamvakaki, M., Ranella, A., Haycock, J. W., ... Claeyssens, F. (2011). Direct laser writing of 3D scaffolds for neural tissue engineering applications. Biofabrication, 3(4), 045005. doi:10.1088/1758-5082/3/4/045005

65. Raviv, D., Zhao, W., McKnelly, C., Papadopoulou, A., Kadambi, A., Shi, B., ... \& Tibbits, S. (2014). Active printed materials for complex self-evolving deformations. Scientific reports, 4(1), 1-8. doi: 10.1038/srep07422

66. Zhang, Y. S., Aleman, J., Shin, S. R., Kilic, T., Kim, D., Shaegh, S. A. M., ... \& Khademhosseini, A. (2017). Multisensor-integrated organs-on-chips platform for automated and continual in situ monitoring of organoid behaviors. Proceedings of the National Academy of Sciences, 114(12), E2293-E2302. doi: 10.1073/pnas.1612906114

67. Shin, S. R., Zhang, Y. S., Kim, D. J., Manbohi, A., Avci, H., Silvestri, A., ... \& Khademhosseini, A. (2016). Aptamer-based microfluidic electrochemical biosensor for monitoring cellsecreted trace cardiac biomarkers. Analytical chemistry, 88(20), 10019-10027. doi: 10.1021/acs.analchem.6b02028

68. Shin, S. R., Kilic, T., Zhang, Y. S., Avci, H., Hu, N., Kim, D., ... \& Khademhosseini, A. (2017). LabelDFree and Regenerative Electrochemical Microfluidic Biosensors for Continual Monitoring of Cell Secretomes. Advanced Science, 4(5), 1600522. doi: 10.1002/advs.201600522

69. Hüseyin, A. V. C. I., GÜZEL, F. D., Salim, E. R. O. L., \& Akpek, A. (2017). Recent advances in organ-on-a-chip technologies and future challenges: a review. Turkish Journal of Chemistry, 42(3), 587-610. doi:10.3906/kim-1611-35

70. Akpek, A., Öztürk, A. B., Alarçin, E., Huseyin, A. V. C. İ., \& ADALI, M. A. Recent Advances in 4D Bioprinting. Research Journal of Biomedical and Biotechnology, 1(1), 20-23. 